NBER WORKING PAPER SERIES

A FRAMEWORK TO COMPARE ENVIRONMENTAL POLICIES

Don Fullerton

Working Paper 8420

http://www.nber.org/papers/w8420

NATIONAL BUREAU OF ECONOMIC RESEARCH

1050 Massachusetts Avenue

Cambridge, MA 02138

August 2001

This paper was presented as a special lecture on "Teaching Environmental Economics" at the Southern Economic Association meetings on November 10, 2000 in Arlington, VA. I am grateful for financial assistance from Redefining Progress, and for helpful comments and suggestions from Jeff Hamond, Gib Metcalf, and Gary Wolff. This paper is part of NBER's research program in Public Economics. The views expressed herein are those of the author and not necessarily those of the National Bureau of Economic Research or Redefining Progress.

(C) 2001 by Don Fullerton. All rights reserved. Short sections of text, not to exceed two paragraphs, may be quoted without explicit permission provided that full credit, including (C) notice, is given to the source. 
A Framework to Compare Environmental Policies

Don Fullerton

NBER Working Paper No. 8420

August 2001

JEL No. H20, H23, Q21

\begin{abstract}
$\underline{\text { ABSTRACT }}$
This paper builds a single model that can be used to show efficiency and distributional effects of eight different types of environmental policies (including taxes, subsidies, regulations, permits, and legal liability). All eight approaches can be designed to have the same efficiency effects, even while they have different distributional effects. For further evaluation of these policies, the paper discusses other criteria outside the simple model (including administrative efficiency, enforcement capabilities, and political feasibility). The paper ends with a discussion of likely trade-offs among these often-competing objectives of environmental policy.
\end{abstract}

Don Fullerton

Department of Economics

University of Texas at Austin

Austin, TX 78712-1173

and NBER

dfullert@eco.utexas.edu 


\section{A Framework to Compare Environmental Policies}

\section{Introduction}

To analyze environmental policy proposals, it is important to determine the conditions under which some policies might work better than others. When will a pollution tax work better than the sale of permits or some other alternative? Which is easier to administer or to enforce? Does one policy apply better to some kinds of pollutants than to others? Which policy has a greater chance of getting enacted? This paper provides a framework to compare alternative policies. For each pollutant, in each context, one policy may be more efficient while others better account for competing objectives like administrative efficiency, political feasibility, and fairness.

Using this framework, the paper will analyze and compare eight types of policies. Clearly no single policy instrument will work best in all cases. Under some circumstances, command and control (CAC) instruments might be necessary, in either of two forms: (a) emission restrictions, sometimes called "performance standards," or (b) technology restrictions that might be called "design standards." If emissions are difficult or impossible to measure, for example, then the authorities can at least enforce rules that require the proper installation of the required pollution control equipment such as a flue-gas desulfurization unit (scrubber) on every electric power plant, or a catalytic converter on every automobile.

In other cases that are important to identify, these command and control instruments can be replaced by "incentive" instruments such as taxes, subsidies, or permits. As suggested by Arthur Pigou (1932), the pollution problem could be addressed by (a) taxes on the pollution, or (b) subsidies to abatement. A Pigouvian tax applies to the pollutant itself, rather than to output, at a rate equal to the pollutant's marginal environmental damages (MED). The term "incentive instruments" includes both the Pigouvian tax and the subsidy to abatement, and it includes two other policies that involve permits such as those traded by electric utilities under the Clean Air Act Amendments of 1990. Those permits could be (a) "grandfathered," or handed out to existing firms in proportion to past emissions, or (b) sold at auction by the government. A simple analytical model is used below to demonstrate conditions under which the Pigouvian tax is equivalent to a government sale of permits.

Much of the environmental economics literature finds that the use of incentives is more "cost-effective" than command and control restrictions. ${ }^{1}$ With imperfect information, the regulatory authorities may or may not know what is the cheapest form of abatement technology. Thus CAC regulations may require technology that is more expensive than necessary. With a tax or a price per unit of emissions, however, each

1. See reviews of this literature in Bohm and Russell (1985), Cropper and Oates (1992), and Stavins (2000). 
firm has incentives to find and to undertake any form of abatement that is cheaper than buying a permit. Since only the cheapest forms of abatement are undertaken, these incentive policies can minimize the total cost of achieving any given level of pollution protection. So far, this "cost-effectiveness" argument does not distinguish between taxes, subsidies, permits that are handed out, or permits sold at auction.

Yet the hand-out of permits does not raise any revenue. Thus a new literature in environmental economics concentrates on a distinction between policies that raise revenue (like a tax on pollution or the sale of permits) as opposed to polices that do not raise revenue (like the handout of permits, or a command and control restriction on emissions). ${ }^{2}$ The model below will be used to reflect on this distinction as well.

So far, we have listed two CAC policies, two Pigouvian solutions, and two versions of a permit policy. Yet in some cases with well-defined property rights, even with pollution, Ronald Coase (1960) shows how the private market can still achieve economic efficiency on its own. Government does not need to intervene at all, except perhaps to help enforce property rights through a court system. Such a Coase solution could specify either that (a) the "victim" owns the "right" to be free of this pollutant, so the firm must buy those rights, or that (b) the "polluter" owns the rights to pollute, so the victim must pay the firm. The surprising result of the Coase theorem is that efficiency is achieved either way. When contemplating another unit of pollution, the firm faces the same incentives whether it has to pay damages to the victim or instead forgoes a payment from the victim.

When the conditions of the Coase theorem break down, then the government can improve welfare by a pollution tax or regulation. Each of these policies has been described and analyzed before, many times, but the purpose of this paper is to integrate all of them into a single model that can be used to show when they are equivalent, when they differ, and how they differ.

The starting point for our analysis is a simple but standard model with no administrative cost, no enforcement problems, competitive firms, and perfect certainty. Under these conditions, we show the equivalence between emission taxes and sale of permits. Both have the same effects on pollution, and the same collection of revenue. For all eight types of policies, the same model is used to show effects on profits, on consumers, and on those who gain from environmental protection. The paper will then consider more complicated circumstances, in order to help policymakers choose among these policies. With uncertainty, for example, taxes and permits are no longer

2. For example, see Parry (1997) and Goulder, Parry, and Burtraw (1997). Fullerton and Metcalf (2001) point out that efficiency can be increased without necessarily raising revenue, so long as the policy can avoid the creation of privately-retained scarcity rents. See below. 
equivalent (Weitzman, 1974).

For each different pollutant, a different policy may be more feasible to enact, less costly to administer, or easier to enforce. For sulfur dioxide, authorities have been successful with the continuous emissions monitoring necessary to enforce the permit requirements, because electric utilities are large point sources whose emissions can be monitored economically. For other types of emissions, however, measurement may be difficult or impossible. In general, the paper will evaluate these polices with respect to criteria such as (1) economic efficiency, (2) administrative efficiency, (3) monitoring and enforcement capability, (4) information requirements and the effects of uncertainty, (5) political and ethical considerations, (6) effects on prices that might shift the distribution of burdens between high and low income groups, between age groups, or between regions of the country, (7) other distortions such as taxes, imperfect competition, or trade barriers, and (8) flexibility in the regulations to deal with transitions and dynamic adjustments.

\section{Analytical Model}

In order to abstract from distributional issues, initially, this section develops a simple model with $\mathrm{N}$ identical individuals who have time and other resources they can sell in the market to earn income that can be used to buy goods. These individuals each maximize utility defined over various clean goods, dirty goods, leisure, environmental quality, and a government-provided public good. We will show the initial equilibrium with an uncorrected externality, and we will show the "social optimum" equilibrium. In the simplest model, several different kinds of policies will shift the economy to the same socially-optimum allocation of resources.

A dirty good in this model might be one that creates externalities through consumption of the good, like cigarettes or gasoline, or it might be one that creates externalities during production of the good, like electricity or steel. In other words, the good might be associated with a fixed amount of pollution per unit, or it might have variable emissions per unit of output.

A general production function for the dirty industry might be written with both the output $\mathrm{Y}$ and the waste by-product $\mathrm{Z}$ on the left-hand side, where both are produced using inputs like labor L, capital $\mathrm{K}$, and other resources $\mathrm{R}$. Using a device common in environmental economics, however, we simply re-arrange the equation to solve for output in terms of the other variables:

$$
\mathrm{Y}=\mathrm{F}(\mathrm{L}, \mathrm{K}, \mathrm{R}, \mathrm{Z})
$$

In other words, we view emissions as an input with its own downward-sloping marginal product curve (since additional units of emissions are successively less crucial to production). Therefore, in our model, the "dirty" output is produced using labor, capital, 
other resources, and "emissions." These emissions Z may include gaseous, liquid, or solid wastes. These wastes themselves entail some private marginal cost (PMC) to the firm for removal and disposal.

This static model considers only one time period, with no saving decision. We assume perfect certainty, no transactions costs, perfect competition, and constant returns to scale production. ${ }^{3}$ Thus the variables above can be measured in amounts per capita, but overall environmental quality is determined by total emissions:

$$
\mathrm{E}=\mathrm{E}(\mathrm{NZ})
$$

Each individual gets utility from per-capita amounts of each nonpolluting good $(\mathrm{X})$, polluting good $(\mathrm{Y})$, a good produced at home $(\mathrm{H})$, the total amount of a nonrival public good $(\mathrm{G})$ provided by government using tax dollars, and from environmental quality (E):

$$
\mathrm{U}=\mathrm{U}(\mathrm{X}, \mathrm{Y}, \mathrm{H}, \mathrm{G}, \mathrm{E})
$$

The individual maximizes this utility subject to a budget. Each has endowments of time and other resources, and each decides how much of these endowments to sell on the market for wage and rental income to buy $\mathrm{X}$ and $\mathrm{Y}$. Remaining time and resources are used to produce the home good, $\mathrm{H}$ (child care, gardening, or leisure). The individual chooses $\mathrm{X}, \mathrm{Y}$, and $\mathrm{H}$, but each faces a given amount of $\mathrm{G}$ and $\mathrm{E}$. In other words, the individual cannot choose environmental quality, because it is determined by everybody else. Assuming $\mathrm{Z}$ has a negative effect on $\mathrm{E}$ in equation (2), then production and consumption of the dirty good has a negative external effect on other people. The dollar value of the lost utility to all individuals from a marginal increase in emissions is called the "marginal environmental damage" (MED).

These assumptions are sufficient to specify a general equilibrium model, with many markets and prices. The literature includes many examples of such general equilibrium models. ${ }^{4}$ To facilitate exposition, however, we can reduce this general model to a partial equilibrium model of just one market. To do so, we make three additional assumptions. First, we assume that the private cost per unit of a particular type of emissions is fixed at a price $\mathrm{P}^{\circ}$. This price just reflects the cost of resources necessary for removal and disposal of this waste. Second, we assume that the demand curve for these emissions is fixed. This demand reflects the marginal benefit of this pollution to production (which, in turn, reflects the benefit to consumers of being able to

3.These considerations might also affect the choice among policy instruments. As reviewed below, other models have analyzed uncertainty (Weitzman, 1974), monitoring and enforcement costs (Russell, 1990), and transactions costs (Stavins, 1995).

4. Examples include Ballard and Medema (1993), Bovenberg and de Mooij (1994), Goulder, Parry and Burtraw (1997), and Fullerton and Metcalf (2001). 
buy the final product). This demand is what somebody is willing to pay for the right to pollute. Third, we assume that lump sum taxes are available, so that government can acquire all necessary revenue without resorting to taxes that distort other markets (such as for labor or investment). We talk about relaxing these assumptions later.

These assumptions allow us to look at a "market" for emissions separately from other markets, using the partial equilibrium diagram in Figure 1. The horizontal axis represents the amount of this pollution $(Z)$, and the vertical axis represents a price or cost (in dollars per unit of emissions). Since the private cost per unit of emissions $\mathrm{P}^{\circ}$ is fixed, the firms face a flat private marginal cost (labelled PMC). The demand for pollution (labelled "marginal benefits") starts out high, because some minimal level of pollution is crucial to production, and it slopes down as additional units of pollution are successively less crucial. In the special case where this pollutant is fixed per unit of output, this curve can be interpreted as the demand for the output. Only in this special case can a tax on output reduce damages effectively. In the absence of any regulations or taxes, firms or consumers would keep polluting as long as the marginal benefits exceed the private cost, and they would stop where the marginal benefit of pollution intersects the private marginal cost. Thus, unregulated pollution is at point $\mathrm{Z}^{\circ}$.

Yet the social cost of pollution is higher than the private cost, because it imposes negative external costs on others. The social marginal cost (SMC) of pollution includes the private marginal cost plus marginal environmental damages (MED). The social marginal cost curve in Figure 1 starts slightly above the private cost to indicate that the very first unit of pollution has only small external cost, but the upward slope indicates that successive units of pollution become more costly. It might become very steep, for example, if the air is already dirty enough that one additional unit is enough to send many people to the hospital.

Pollution has social benefits by allowing us to use electricity and other polluting products, and it also has social costs. The net gain to society is maximized by polluting as long as the social benefits exceed the social cost. The intersection indicates the optimal amount of pollution, $Z^{\prime}$, and the problem for policy is to cut pollution from $Z^{\circ}$ to $Z^{\prime}$.

The solution of Arthur Pigou (1932) is to impose a tax per unit of pollution, at a rate $t_{z}$, equal to the marginal external damages per unit of pollution at the optimum. This Pigouvian tax raises the private cost of pollution from $\mathrm{P}^{\circ}$ to $\mathrm{P}^{\prime}=\mathrm{P}^{\circ}+\mathrm{t}_{\mathrm{z}}$. Then firms (or consumers) face costs $\mathrm{P}^{\prime}$ and stop at $\mathrm{Z}^{\prime} .{ }^{5}$ The tax revenue would be the tax rate times the amount of pollution subject to tax, that is, the rectangle area $2+3$ in the

5. Alternatively, if the tax rate could rise with pollution, then the firm could be made to face the entire SMC curve in Figure 1. Such a firm would compare marginal benefits to SMC and choose Z'. For elaboration on this point, see Kaplow and Shavell (1997). 
figure. In a first-best world, with no other distortions, welfare improves by the triangle area $5+6$. This area measures the extent to which social marginal cost exceeds the (social) marginal benefits, for each of those units of pollution beyond $Z^{\prime}$, up to $Z^{\circ}$.

To see the effects on each different actor in the economy, we pause to consider other areas in Figure 1. First, note that the Total Benefit of pollution is the area under the Marginal Benefit curve. Somebody is willing to pay some high amount for the first right to emit a unit of pollution, and less for each successive unit out to $Z^{\circ}$, so the total benefit of that pollution is area $1+2+3+4+7+8$. Yet they only have to pay $\mathrm{P}^{\circ}$ for each unit, so the private cost of $Z^{\circ}$ units is area 7+8. "Consumer Surplus" is defined as the benefits in excess of the cost: it is the net benefits to consumers, area $1+2+3+4$. Now we see the problem with this tax: it raises the cost of pollution to $\mathrm{P}^{\prime}$ so that consumer surplus is reduced to area 1 . The fall in consumer surplus is the trapezoid $2+3+4$. This is the cost of environmental protection.

The "victims", of course, gain from environmental protection. The Total Social Cost of pollution is the area under the Social Marginal Cost -- the area $3+4+5+6+7+8$. Some of that cost is private cost incurred by the firm (area 7+8), so the external cost to the "victims" is the difference (area $3+4+5+6$ ). Note that this includes the small external cost of the first unit of pollution, plus the higher external cost of each successive unit out to $Z^{\circ}$. If policy is able to cut pollution from $Z^{\circ}$ back to only $Z^{\prime}$, then the external cost of the remaining pollution is only area 3 . The reduction in the cost of pollution is the gain to the "victims," area $4+5+6$.

What happens to the firm? With perfect competition and constant returns to scale, as assumed earlier, the firm earns only a normal return on its operations. In the case with a fixed amount of pollution per unit of output, the firm sells $Z^{\circ}$ units at a price of $\mathrm{P}^{\circ}$ per unit, so sales revenue is area 7+8. But the private cost of production is also $\mathrm{P}^{\circ}$ per unit, so total cost is also area 7+8. Equilibrium profits are zero. Then when the tax is imposed, costs rise to $\mathrm{P}^{\prime}$ and the equilibrium price rises to $\mathrm{P}^{\prime}$, so the firm still earns zero profits!

What happens to the workers? At the old equilibrium, firms received no profits because they were paying all sales revenue (area 7+8) to the factors of production (labor, capital, and other resources). At the new equilibrium, the firms use fewer inputs and produce less, but they still pay all net-of-tax sales revenue (now just area 7) to the factors of production. Area 8 represents the former payments to factors that are now laid off. However, the simple competitive model described here considers changes to the price and quantity in this market, with no change to prices in other markets. In other words, "partial equilibrium" means that the wage rate and interest rate are fixed. Mobility of labor and capital ensures that they cannot suffer: those who lose jobs in this industry find other jobs in some other industry where they earn the same return that they 
did before. Thus workers are held harmless.

Most economists think these results are completely obvious, and most others think they are completely wrong. If the firms earn zero profits before the tax, and zero profits after the tax, then why would they care about the imposition of the tax? Surely somebody in the industry is injured, and would lobby long and hard to avoid imposition of the tax. The answer to this puzzle is in the transition from one equilibrium to the other. When the tax is first imposed, firms in the industry take a capital loss, cut back production, sell equipment, and lay off workers. Those workers must move, receive new training, and find new jobs. The phrase "at the new equilibrium" means "after all the dust has settled." These resources are eventually re-employed at the same wage they received before; the transition costs simply are not captured in the model.

We use the simple model to clarify all of the equilibrium effects and to show theoretical equivalences among these policies. Considerations outside the model are then used to show where the policies differ. In particular, we devote a whole section below to transition effects.

\section{The Menu of Policy Options}

We now review the eight types of environmental policies, by the number (under four headings that each have two types).

\section{Pigouvian Solutions}

\section{a. Tax on Pollution}

All of the equilibrium effects of this tax are shown in the first row of Table 1. Buyers pay more for the product, so they lose consumer surplus area $2+3+4$. Firms still earn zero profits. The government raises revenue area $2+3$, and the net loss, so far, is area 4 . Victims gain from the reduction in environmental damages, area $4+5+6$, so the net gain to society is area $5+6$, just as stated above. This net gain is the "efficiency effect" from correcting the externality. It reflects the fact that the costs of that extra pollution exceeded the benefits of it (by area $5+6$ ).

The first main result from this diagram and table is now clear: while some may promote this reform on the basis of the net gain to society, not everybody shares in the gain. Consumers lose, while environmentalists gain, and these different groups are unlikely to agree on the merits of the reform. Displaced workers may also oppose it, making the net gain hard to obtain. ${ }^{6}$

Interestingly, the U.S. does not employ any good examples of a Pigouvian tax on pollution. The IRS Statistics of Income identifies four "environmental" taxes, on: (1)

6. The revenue $(2+3)$ can be used to reduce other taxes and thus to offset at least some of the loss to consumers $(2+3+4)$. If individuals differ, then net gains may accrue to anyone who buys less than the average amount of the dirty good. 
petroleum, for the Oil Spill Liability Trust Fund (OSLTF) and Superfund; (2) chemical feedstocks, for Superfund; (3) ozone-depleting chemicals, for the general fund; and (4) motor fuels, for the Leaky Underground Storage Tank (LUST) fund. These are called "environmental taxes" not because they discourage pollution, but because their revenues are used for environmental purposes such as the Superfund clean-up of contaminated sites. Taxes apply to all petroleum and chemical purchases, not to chemical or petroleum wastes, and thus do not affect the proportion of those inputs that become waste by-products. They are not designed to discourage pollution but to collect from those deemed responsible for pollution. ${ }^{7}$

\section{b. Subsidy for Abatement}

The other Pigouvian solution is for the government to pay the firm to cut back on polluting production. Suppose the policy states that each firm will be paid $t_{z}$ (the same amount as before, $\mathrm{P}^{\prime}-\mathrm{P}^{\circ}$ ) for every unit of pollution reduced from the initial point $Z^{\circ}$. Then for each unit of pollution, the firm bears a "cost" equal to the subsidy it must give up by not reducing that unit of pollution. The full cost of pollution is $\mathrm{P}^{\prime}$, the private marginal cost $\left(\mathrm{P}^{\circ}\right)$ plus the subsidy foregone. The firm pollutes as long as the marginal benefits exceed this cost $\mathrm{P}^{\prime}$, that is, to $\mathrm{Z}$ '. In other words, the subsidy for abatement induces the firm to abate. Because the abatement is the same as before, the net efficiency gain is the same as before -- area $5+6$.

Of course, the directions of the payments are very different, as shown in row $1 \mathrm{~b}$ of the table. Instead of collecting $2+3$ of revenue, the government now pays $t_{z}$ for each unit cut back from $Z^{\circ}$ to $Z^{\prime}$, an amount equal to area $4+5$. The firms receive those payments. In addition, the cost of production rises from $\mathrm{P}^{\circ}$ to $\mathrm{P}^{\prime}$, including the opportunity cost of the subsidy foregone, so the equilibrium price rises to $\mathrm{P}^{\prime}$. Consumers pay this higher price and lose consumer surplus area $2+3+4$. The firms receive the higher price $\mathrm{P}^{\prime}$, but actual cost of production is still only $\mathrm{P}^{\circ}$, so area $2+3$ becomes profits. The firms get those profits $(2+3)$ plus the subsidy $(4+5)$. Victims gain area $4+5+6$, and the row sum is the net gain, area $5+6$.

How do the firms obtain profits this time, despite perfect competition? The answer is that the market is not really competitive any longer. Only existing firms at the time of the policy change are told that they can receive a subsidy for cutting pollution below prior levels. Nobody else is eligible for the subsidy, so existing polluters get a special advantage. In fact, to state the problem more vividly, consider that the

7. The tax on chlorofluorocarbons (CFC's), however, does not finance a cleanup fund. Like a Pigouvian tax, it helps prevent further harm by reducing the future use of ozonedepleting chemicals. It applies fairly closely to the activity causing environmental harm, and it even applies at a rate that varies with the degree of environmental harm (Barthold, 1994). 
government through its antitrust policy usually prohibits firms from colluding in attempts to cut back production, raise price, and make profits. Yet this environmental policy actually pays the firms to cut production, raise price, and make profits. As a consequence, it may not seem like a viable policy. We include the subsidy policy in this list for three reasons. First, the complete list allows us to point out the symmetry among the policies: many different policies can achieve the same incentives and thus the same net efficiency gain, but they each have different distributional consequences. Second, this subsidy is not that different from other policies that implement transfers to farmers, through higher crop prices, by paying them not to produce. Third, these features of environmental policy may become relevant if particular aspects of proposed policies tend to restrict entry, because those restrictions might help raise product prices unnecessarily.

Other subsidy policies might not raise price and provide profits. If all firms are subsidized on their purchase of abatement equipment, then all firms have lower costs of production. This policy could reduce the equilibrium output price, and the difference is very important for "other distortions" discussed below -- in the case without lump sum taxes. $^{8}$

\section{Permits}

Environmental economists have proposed permit polices for years, in various contexts, ${ }^{9}$ but the best example of an actual permit policy is the Clean Air Act Amendments of $1990 .{ }^{10}$ In terms of Figure 1, this policy would set up a system of $Z^{\prime}$ tradeable permits. The right to emit one ton of sulfur dioxide sells for about $\$ 150$ on the Chicago commodities exchange. Anybody who wants to pollute faces a cost per ton equal to the private marginal cost of disposal $\left(\mathrm{P}^{\circ}\right)$ plus 150 . The higher cost of production raises the equilibrium output price, to $\mathrm{P}^{\prime}$.

A "scarcity rent" is created because government has restricted the amount of production, and consumers place higher value on the remaining units of production. This scarcity rent is the value of $Z^{\prime}$ permits, area $2+3$ in Figure 1 . When the price rises to $\mathrm{P}^{\prime}$, consumers lose surplus area $2+3+4$. The "victims" of the pollution gain from the reduction in pollution, and the dollar value of this gain is area $4+5+6$. Thus the net gain (the row sum in Table 1) is still area $5+6$ as before. The remaining question is: who gets the scarcity rents?

\section{a. Handed out to Firms}

8. For more complete analyses of environmental subsidy policies, see Ballard and Medema (1993) or Parry (1998).

9. Examples of such proposals and discussion are in Hahn (1989) and Stavins (2000).

10. Pub.L 101-549, November 15, 1990, 104 Stat. 2399. 
Under the Clean Air Act Amendments, and in other proposals, the initial permits are allocated in proportion to a prior year's emission levels. For example, every firm might be given a number of permits equal to 80 percent of the previous year's emissions. The firms may argue that the regulation itself is onerous enough, and they ought to be "grandfathered." Yet any permit recipient can use the permit to produce and to sell output at this new higher output price. Since actual costs are still $\mathrm{P}^{\circ}$, those firms make profits of area 2+3. By the way, it does not matter if the permit recipient goes out of business, because each permit can still be sold for $\$ 150$. Anybody who is handed an initial allocation of permits is handed a private profit.

\section{b. Sold at Auction}

Instead of handing out initial permits, the government could sell them at auction. Since output is restricted to $Z^{\prime}$, the firms know that the equilibrium output price will be $\mathrm{P}^{\prime}$. Their actual production costs are $\mathrm{P}^{\circ}$, so they are willing to pay an amount $\left(\mathrm{P}^{\prime}-\mathrm{P}^{\circ}\right)$ for each permit. That price, times the $Z^{\prime}$ number of permits, provides rectangle $2+3$ as revenue to the government. Table 1 shows that all effects of this sale of permits (row 2b) are equivalent, in this model, to the effects of a Pigouvian tax on emissions (row 1a). Either way, the consumers lose $2+3+4$ of surplus, the government gets $2+3$ of revenue, and the environmentalists gain $4+5+6$ from the reduction in damages. The total of those gains minus loses is the net gain, area $5+6$. This discussion shows that the distributional effects are the same for the tax and the sale of permits (but the section on uncertainty below shows how they differ).

\section{Command and Control}

As mentioned above, actual U.S. environmental policies do not use taxes to discourage pollution. Instead, actual policies tend to employ command-and-control regulations. In the model of Figure 1, a CAC "performance standard" might be represented by the mandate that "pollution shall not exceed Z'." If designed properly, and if revenue is not an issue, ${ }^{11}$ such a regulation can move the economy to the same reduced optimal amount of pollution $\left(Z^{\prime}\right)$ and provide the same triangle welfare gain (area 5+6). The figure cannot be employed to represent a "technology standard," in a comparable fashion, but it can be used to compare two different CAC policies. We consider first a performance standard that just restricts quantity and allows price to rise, and we then consider a policy that attempts to prevent the price from rising.

\section{a. Quantity Restriction}

Suppose authorities simply restrict pollution to no more than $Z^{\prime}$. Since the marginal benefit of pollution exceeds the private marginal cost at $Z^{\prime}$, firms will pollute

11. Recall our temporary assumption that lump sum taxes are available, so government can acquire all necessary revenue without resorting to distorting taxes on labor or capital. 
up to the legal limit. At this point, a marginal unit of pollution continues to have private disposal cost equal to $\mathrm{P}^{\circ}$, but its marginal benefit or value in production is $\mathrm{P}^{\prime}$. Firms are willing to pay the difference $\left(\mathrm{P}^{\prime}-\mathrm{P}^{\circ}\right)$ for the right to pollute, whether or not they are allowed to pay for this right. If no trades are allowed, and this value is not observed as a market price, then the difference $\left(\mathrm{P}^{\prime}-\mathrm{P}^{\circ}\right)$ is a "shadow price". Anybody who is allocated the limited rights to pollute can use a unit of pollution to create value equal to $\mathrm{P}^{\prime}$, at a cost of only $\mathrm{P}^{\circ}$. The difference is a profit, or "scarcity rent."

To at least some extent, a restriction on the amount of pollution is a restriction on the amount of output, which enables firms in equilibrium to charge a higher price for their output. ${ }^{12}$ Given this higher price of output, the right to pollute is more valuable. The "scarcity rent" is the increase in the value of the right to pollute one unit. It is reflected, for example, in the price of a tradeable permit for one ton of sulfur-dioxide emissions. But command-and-control restrictions create similar scarcity rents even when pollution rights are not tradeable. Consider the simple case where the production technology requires a fixed amount of pollution per unit of output, and where the government requires every firm to cut pollution to 80 percent of last year's level. Then firms must cut production to 80 percent of last year's level. The price of output must rise, for the market to clear, but actual production costs have not changed. Normally firms are prohibited from agreements to restrict output, but this kind of regulation essentially requires them to restrict output. The result is super-normal profits.

In the case with variable pollution per unit of output, the policy restricts pollution rather than output, but it still provides scarcity rents. Take the simple case with many identical firms, for example, and suppose the government hands out permits to each, in amounts equal to 80 percent of each firm's previous level of the pollutant. These permits would certainly trade at a positive price and provide profits to the firm for reasons discussed above. But if all firms are identical, then these firms would have no reason to buy or sell permits to each other. They don't care whether they are allowed to trade those permits. Thus the 80 percent strict quantity limit must have the same effects as handing out valuable permits equal to 80 percent of last year's level. In other words, the CAC quantity restriction must create the same kinds of scarcity rents as tradeable permits, even with variable pollution per unit of output.

In Figure 1, the CAC quantity restriction raises price to $\mathrm{P}^{\prime}$, and consumers lose surplus area $2+3+4$. Firms earn scarcity rents $\left(\mathrm{P}^{\prime}-\mathrm{P}^{\circ}\right)$ for each of the $\mathrm{Z}^{\prime}$ units, for profits of area $2+3$. In a case with no external environmental effects, the efficiency loss from this legal cartel's monopoly profits would be area 4. But with environmental effects, the cutback in pollution reduces external damages (area $4+5+6$ ). The net gain 
(row sum in Table 1) is area $5+6$.

Table 1 shows that all effects of this CAC quantity restriction (row 3a) are equivalent, in this model, to the effects of handing out permits (row $2 \mathrm{a}$ ).

\section{b. Quantity and Price Restrictions}

If or when Congress contemplates such quantity restrictions, they might notice that firms could charge higher prices and make supernormal profits. In an attempt to protect consumers, legislators might be tempted to forbid such price increases. Suppose the law were to state that firms cannot pollute beyond $Z^{\prime}$ and cannot charge a price above $\mathrm{P}^{\circ}$. In terms of Figure 1, if that policy were successful, then consumers would be able to buy $Z^{\prime}$ units for the low price of $\mathrm{P}^{\circ}$ and would still receive consumer surplus area $1+2+3$. They would not be able to purchase the extra desired units at that low price, however, so they would lose consumer surplus area 4 . The table's row $3 b$ shows that environmentalists ("victims") would gain area $4+5+6$.

One point of this analysis is that all of the alternative policies in this simple model have identical efficiency effects (net gain of 5+6). They all reduce pollution to the "optimal" quantity, and economic efficiency is defined in terms of quantity allocations. The only differences involve distributional effects, such as who gets the scarcity rents. This rectangle (area $2+3$ ) might go to firms as profits, to government as tax revenue, or to consumers as surplus.

Notice, however, that the combination of price $\mathrm{P}^{\circ}$ and quantity $\mathrm{Z}^{\prime}$ is not on the demand curve. At the low price $\mathrm{P}^{\circ}$, consumers would really like to buy more of the good. And because of this excess demand, the law must also specify an allocation mechanism. Which consumers are allowed to buy at the artificially low price? The law may allocate "coupons", but these coupons essentially become the "permits" of the previous case, as they allow their holders to capture the scarcity rents -- area $2+3$. If the rights are not legally tradeable, a black market may arise. Buyers still lose consumer surplus $2+3+4$.

Alternatively, the law may allocate the restricted quantity by allowing anybody to stand in line. In this case, many people waste time unnecessarily. In fact, the value of the time they are willing to stand in line is exactly the value $\left(\mathrm{P}^{\prime}-\mathrm{P}^{\circ}\right)$ that they are willing to pay for the right to buy the good at the low price $\mathrm{P}^{\circ}$. In this case, area $2+3$ is completely wasted by standing in line. Or, in the case of some other allocation rule, potential recipients are willing to waste area $2+3$ of resources on lobbying Congress for the right to buy at the artificially low price. This behavior and wasteful outcome is called "rent seeking" by Krueger (1974). Consumers are really paying the higher price $\mathrm{P}^{\prime}$, so they lose consumer surplus $2+3+4$, and nobody gets the scarcity rents. Environmental damages are still reduced by $4+5+6$, but the overall net gain to society may be positive or negative, depending on the size of the gain $5+6$ relative to the social 
loss of $2+3$.

For all of these reasons, the "quantity and price restriction" is not recommended. It is included here for completeness, and to point out potential pitfalls of policies that may try to allocate scarce resources by coupons or queues. The basic problem is the attempt to enforce a combination $\left(\mathrm{Z}^{\prime}, \mathrm{P}^{\circ}\right)$ that is not on the demand curve. In other words, Congress cannot repeal the "Law of Supply and Demand."

\section{Coase Solutions}

All of the policies described above are government interventions to correct a failure in the private market, so a proper analysis of these policies must carefully determine exactly when and how the market fails. Coase (1960) clarifies the conditions under which the private market works perfectly well on its own, without government intervention, even when production causes environmental damages. If the damaged party can sue the producers, and make them pay for damages, then producers face the true social costs of production. Firms then continue to produce only as long as the price they can get (the marginal benefits to consumers) exceeds the true social costs of production (the SMC curve in Figure 1). Firms break even by producing Z', the socially- optimal quantity, and any further tax would make them cut back below the optimal quantity.

Three conditions are required. First, property rights must be well defined. Either the "victims" have the right to be free of the pollutant (so that firms must pay them for the right to pollute) or firms have the right to pollute (so that others must pay them to cut back). Second, bargaining costs must be low enough for these parties to find each other, negotiate a price, and ensure this "optimal" outcome. Third, exclusion must be feasible. This last requirement means that no other parties are able to free-ride on the agreement. If some of the victims are paying the firm to cut back, then others may enjoy the benefits of reduced pollution without having to pay. They have incentive to underreport their true willingness to pay to reduce the pollution, so the agreement then does not reflect all social costs and benefits. Excludability allows a provider to extract a price, so nonexcludability makes a market fail.

These requirements essentially mean that the number of affected parties must be fairly small. With only one polluter and one "victim," for example, they can presumably find each other and write a contract that specifies a particular payment to guarantee a particular outcome (i.e., Z'). If so, the market works. With thousands of parties, however, the negotiations become difficult or impossible. When is the number of parties too high to make a market for this pollutant? It depends on the circumstances in each case. The point for the moment is just that the Coase solution might work, and we can use the same diagram to show how it works.

The surprising point of the Coase theorem is not just that the private market 
might work, and achieve the optimal quantities by itself, but that these three conditions are enough to guarantee this optimal outcome regardless of which party has property rights. The assignment of property rights affects the distribution of well-being, but not the efficiency of the economy.

\section{a. "Victim" has Property Rights}

Suppose that the firm was initially producing out to $\mathrm{Z}^{\circ}$, while charging $\mathrm{P}^{\circ}$, and suppose that property rights are then established such that the firm must pay for damages. If other conditions of the Coase Theorem are met, then firms can be made to pay the cost of pollution. The private marginal cost curve is raised from PMC up to SMC in Figure 1, and firms sell $Z^{\prime}$ for a price of $\mathrm{P}^{\prime}$. Consumers pay the higher price and lose consumer surplus area $2+3+4$. External damages are reduced by area $4+5+6$. The result is a net gain of $5+6$, as before, so long as somebody recoups the lost rectangle $2+3$. Who gets these "rents"? The answer depends on relative bargaining strength. By law, in this case, the "victims" can shut down all production unless the firm(s) pay enough. As long as the locations of the curves are measured properly, then the firm is willing to pay an amount up to area $2+3$ for the right to produce $\mathrm{Z}^{\prime}$, and sell it for $\mathrm{P}^{\prime}$ ( since its costs are only $\mathrm{P}^{\circ}$ ). Of course, they would like to pay less than that. Production of $Z^{\prime}$ still causes area 3 of environmental damages, however, so area 3 is the minimum payment that the victims are willing to accept. Undoubtedly they would like to receive more. Therefore the payment, denoted by the symbol "B", will be somewhere between area 3 and area 2+3. As shown in Table 1, row 4a, the firm gets profits $2+3-\mathrm{B}$ (where B might be as large as $2+3$, leaving no profits). The "victims" get reduced damages $4+5+6$ plus the payment $\mathrm{B}$ (which must be at least area 3 to compensate for remaining damages). Thus the victims do well in this case.

\section{b. Polluter has Property Rights}

Alternatively, suppose the polluter is allowed to produce as much as desired. Facing private marginal costs (PMC), production would proceed to $\mathrm{Z}^{\circ}$, but we still assume that competition eliminates any supernormal profits: the sales price matches costs at $\mathrm{P}^{\circ}$. The victims are not happy, since they bear $3+4+5+6$ of damages, but they can improve their own situation by making a deal with producers -- no need for government at all. For each unit cut back from $Z^{\circ}$, The victims are willing to pay up to the MED that the unit would have caused, and such an offer would raise the cost of production to SMC -- the cost of production plus the cost to the firm of rejecting the extra payment. Thus the deal that maximizes joint surplus is a deal to produce $Z^{\prime}$-- the socially-optimal quantity. This deal could be stated in amounts per unit, as just described, or it could be stated as an amount " $\mathrm{C}$ " to cut production directly to the efficient quantity. The victims can share in the efficiency gain if they can negotiate a payment $\mathrm{C}$ that is less than their environmental gains $4+5+6$. Their net gains $4+5+6-\mathrm{C}$ 
must be positive or at least zero (or else they wouldn't agree to the deal). With production cut to $Z^{\prime}$, producers can charge $\mathrm{P}^{\prime}$ from their customers and earn profits plus the payments from the victims $(2+3+\mathrm{C})$. Consumers lose consumer surplus $2+3+4$, so the net gain (row sum) is still area $5+6$.

Producers could be said to make out like bandits in this scenario. They own the rights to produce as much as they want, so others must pay them to cut back. The outcome may sound outrageous, but for two points. First of all, these are not really different groups. Many of us own some corporate stock. We all breath the air, and we all buy commodities. In the simplest model where all $\mathrm{N}$ individuals are identical, then everybody shares equally in the net gain (area 5+6). ${ }^{13}$ The actual distributional outcome depends on whether the firm's stock is concentrated in the hands of a rich few, or held widely by pension accounts of all Americans. Similarly, the damages from any particular pollutant might be felt locally by a few unfortunates or by all Americans. The point is just that payments from the victims to the firm do not necessarily have adverse distributional effects. Suppose, for example, that poor local landholders along a river own the rights to dump mining waste, while rich out-of-state vacationers' groups want to buy these rights, shut down the mines, and use the river for recreational fishing. That deal can improve the environment, but society might not worry about the distributional effects.

Second, as Coase points out, any externality is reciprocal. Suppose the owners of a firm have been producing for years and provide a much-needed commodity to consumers. They feel that their activities simply would not be a problem except for new neighbors who complain. Depending on perspective, either party is a "victim" of the other, and hence the repeated use of quotation marks around the word "victim." For a last example, suppose a river can be used by commercial fishing firms and by logging firms, but that each obstructs the other. Which is a victim of the other? Coase (1960) includes many such examples; the externality is reciprocal.

If the conditions for the Coase theorem fail, as is common with many affected parties, then government has the potential to improve welfare by using a Pigouvian tax, subsidy, or other regulation. Even then, however, intervention is not necessarily warranted. Even if the policy can achieve gains in economic efficiency, it also has costs of administration, compliance, and enforcement (not shown in the figure). Moreover, government often makes mistakes. The policy might not be well designed. Economic efficiency is just one of many criteria for the evaluation of government policy options.

13. In fact, with $\mathrm{N}$ identical shareholder-victims, the choice among the eight solutions is really rather irrelevant. The shareholders also have to suffer the consequences of pollution, so they vote unanimously for the firm to cut production to $Z$ ' without any need for a deal or for policy (Gordon, 1989). 
All of these criteria are listed and discussed next.

\section{Competing Goals and Objectives}

The previous section showed how eight different solutions can be designed to generate the same efficiency gains, and it showed how they generate different distributional effects. This section proceeds to discuss a list of other differences among these policies. Policymakers are constantly torn by tradeoffs among competing policy objectives. In fact, each of the eight objectives below is itself a "category" that includes many considerations or criteria that might help influence the choice of policy. ${ }^{14}$

\section{Economic Efficiency}

The first half of this paper discusses economic efficiency in terms of the optimal amount of pollution. In that theory, production can be restrained either by traditional command and control (CAC) regulations or by market-based incentive (MBI) policies like taxes or permits that impose a price per unit of pollution. More generally, however, economic efficiency also requires minimizing the cost of achieving that abatement. On this basis, these policies are likely to differ. To avoid paying a price per unit of pollution, a firm can choose the cheapest methods for controlling waste: each firm can decide how much to pay to scrap an old process for a new technology, how much to switch to more-expensive low-polluting inputs, how much to pay for control equipment, and how much to pay for remaining pollution. Thus incentives can minimize the total cost of abatement. In contrast, a CAC policy like a "technology standard" is only able to match this efficiency if the regulator knows exactly which combination of abatement technologies minimize costs and can tell each different firm exactly how much of each new technology to purchase, how much to switch fuels, how much to reduce output, and how much to switch output between plants. The information requirements are enormous.

In general, the firm is likely to have much better information than the regulator about the cost and effectiveness of alternative abatement technologies. An MBI policy is likely to impose lower economic costs than a CAC policy, because it induces the firm to find the lowest cost combination of abatement methods. A CAC "performance standard" gives each firm the choice of abatement technology, but it may require all firms to reduce pollution by the same percentage. With a tax or permit system, however, some firms with low abatement cost may undertake most of the total abatement, while other firms with high abatement cost may not abate much at all. Still

14. Similar lists of competing objectives are provided in Break and Pechman (1975) and Bohm and Russell (1985). A large literature discusses the choice among policy options, including Baumol and Oates (1988), Cropper and Oates (1992), Barthold (1994), or Stavins (2000). 
other firms may go out of business -- if they face high abatement costs and low or elastic demand by consumers. Previous researchers have investigated the difference between these policies empirically, and they have found that typical CAC policies are six to ten times as expensive as the minimum abatement cost made possible by market-based policies like taxes or permits. ${ }^{15}$

\section{Administrative Efficiency}

A second goal is to minimize administrative costs to government and compliance costs to firms and taxpayers. Increased complexity of taxes or regulations normally means more instructions, more time filling out forms, and more difficult audits. Yet some complexity might be necessary to identify particular polluting activities. A tax on hazardous waste would better discourage polluting behavior, but taxes on chemical feedstocks and petroleum inputs are probably easier to administer.

The IRS budget is about $\$ 8$ billion per year, which includes spending on equipment and rent as well as salaries of clerks, auditors, and lawyers. This administrative cost is less than $0.5 \%$ of total federal receipts ( $\$ 2$ trillion in 2000 ), so the U.S. is fairly efficient at collecting taxes. ${ }^{16}$ The IRS cannot break down the costs of collecting each tax, and the U.S. has no tax on pollution anyway, so we have no estimates of the administrative cost of collecting environmental taxes.

Environmental regulations also have administrative costs. The budget of the EPA is about $\$ 7.6$ billion per year, but that is a poor indicator of administrative expenses for two reasons. First, the EPA budget includes grants to states and actual abatement expenses, not just administrative costs. Second, additional environmental administrative expenses are incurred by the Interior Department and virtually every other agency that files environmental impact statements. All government agencies promulgate rules that firms must read, interpret, evaluate, and follow. These compliance costs for firms can easily exceed the administrative costs to the government.

The nature and extent of each pollution problem undoubtedly determine for each case whether administrative and compliance costs are lower for traditional CAC regulation or for alternatives policies like taxes or permits. For some pollutants, these

15. See, for examples, Atkinson and Lewis (1974), Seskin, Anderson, and Reid (1983), and other studies surveyed in Cropper and Oates (1992).

16. These figures can be found in the Budget of the United States Government for FY2002, at http://www.whitehouse.gov/omb/budget/. The reason the IRS has relatively low tax collection cost is that it puts most of the cost on the taxpayers. The compliance cost to taxpayers includes not only the dollars paid to accountants and lawyers, but the value of all time spent keeping receipts, reading instructions, and filling out forms. For the individual income tax, Slemrod and Sorum (1984) find that total compliance cost is five to seven percent of revenue. Thus the compliance cost of the income tax is ten times the administrative cost to the IRS. 
costs might be reduced by using simple rules of conduct, rather than by trying to measure the actual amount of the pollution. A tax on illegal dumping of hazardous waste would be relatively difficult to implement. Other cases differ. A tax on carbon dioxide emissions can be implemented relatively easily by measuring the carbon content of each fossil fuel, recording the market purchase of each fuel, and then using scientific relationships between carbon content and $\mathrm{CO}_{2}$ emissions from combustion.

The tax on gasoline presents a good example of the trade-offs. This tax is far simpler than rules about when and where we can drive, and it is also simpler than trying to tax auto emissions themselves. Harrington, Walls, and McConnell (1994) describe remote sensing technologies and on-board devices that might feasibly measure auto emissions, but the administrative and compliance costs would be large.

A final note is that administrative and compliance activities may exhibit economies of scale. Much of the paperwork is a "fixed" cost of calculating the tax base, not a marginal cost of collecting more revenue by raising the rate of tax on a given tax base. Thus the administrative cost or compliance cost as a fraction of tax revenue might be expected to fall as the tax rate and revenue become larger. ${ }^{17}$ The implication is that a tax on any particular externality problem might not be worthwhile unless the externality is big enough to justify a tax rate high enough so that the gains in economic efficiency outweigh the costs of administration and compliance.

\section{Monitoring and Enforcement}

A third goal is to be able to measure the quantity of the regulated pollutant in a way that can discourage evasion. The policy needs to account for methods of avoidance or evasion. A tax applied to each unit of waste brought to a qualified disposal facility might be designed to reflect the social harm from that waste and to discourage generation of waste, but it might just shift disposal away from the qualified facilities and towards improper methods of disposal that can cause worse environmental harm. ${ }^{18}$

The policy needs to reflect monitoring capabilities. A Pigouvian tax may require counting tons of emissions, whereas a design standard simply requires authorities to confirm the use of a particular kind of pollution control equipment. EPA inspectors can easily check that the plant has a working scrubber, but for some kinds of emissions, they

17. Slemrod and Blumenthal (1993) say that "the findings of economies of scale in tax compliance costs is common in studies across countries and across types of tax" (p. 6). For a discussion of systems that optimize administrative costs as well as tax rates, see Slemrod (1990).

18. In some cases, evasion is easy. A tanker truck filled with waste can enter a truck wash, get all the washer spray going, and then open the drain on the bottom of the truck. Another example is that waste oil can easily go undetected if dumped on roadbeds of railroad lines. 
may have too much difficulty trying to confirm the exact number of tons to be able to collect a tax or permit price. Thus the goal of monitoring and enforcement might be met more easily by some kinds of CAC regulations.

The current U.S. gasoline tax may represent the best available example of an incentive-based environmental tax (even though it is not called an environmental tax because it does not finance a cleanup program). Gasoline is a well-defined commodity that can be measured at the pump, and the revenue is substantial -- almost $\$ 35$ billion in 2000. It has incentive effects favorable to the environment since it might help conserve energy and improve air quality. It is still a highly imperfect example, however.

Environmental damages result from emissions, and gasoline is only weakly correlated with emissions. Walls and Hanson (1999) describe how emission rates vary greatly across vehicle age, vehicle maintenance, and styles of driving. ${ }^{19}$

The gasoline tax does not provide the same incentives as the emissions tax to minimize total abatement cost by choosing the efficient combination of technologies, that is, choosing whether to scrap high-emission cars, fix broken emission equipment, or drive less aggressively. All of those incentives would be provided by a true tax on emissions, but auto emissions can only be measured inaccurately and at great expense. Thus the gasoline tax achieves less economic efficiency, but it is easier to monitor and enforce. Congress might be striking the right balance now, but the trade-off may change with technological advances in the measurement of emissions.

\section{Information and Uncertainty}

The simple partial equilibrium model above assumed perfect information, but much research in economics is devoted to problems of imperfect information. In these economic models, the case where everybody has the same imperfect information does not necessarily have important policy implications. In Figure 1, for example, a tax schedule that reflects expected MED will make all firms face the expected SMC of production -- and thus induce them to undertake actions that are expected to maximize social welfare (Kaplow and Shavell, 1997). These results change, however, if the information is one-sided, such as where the firm knows more than the government about what is the least-cost technology and what are the actual emissions. In a model where

19. In a study of a scrappage program, Alberini et al (1994) find that pre-1980 vehicles currently have an average tailpipe hydrocarbon emission rate ( 6.6 grams/mile) that is 26 times the current new car standard $(0.25$ grams/mile $)$. Even a relatively new car might have many times its original emission rate if its pollution control equipment is broken. Because of emissions from cold start-ups, Burmich (1989) finds that a 5-mile trip has almost three times the emissions per mile as a 20-mile trip at the same speed. Sierra Research (1994) finds that a car driven aggressively has a carbon monoxide emission rate (39 grams/mile) that is almost twenty times higher than when driven normally $(2.2$ grams/mile). 
authorities cannot know for sure which firms are cheating, they must set three important policy variables: the rate of tax, the rate at which firms get audited, and the rate at which cheaters are penalized. These models can calculate the "optimal" audit rate and penalty that induce the optimal number of firms to comply. ${ }^{20}$

Some other literature considers cases where government does not have complete flexibility about the kind of taxes or other policies that can be implemented. In particular, Weitzman (1974) considers the case where government cannot set a tax schedule that reflects the rising expected marginal external damages in Figure 1. Instead, he assumes that the government can only set one tax rate on all units of pollution. He assumes no problems of enforcement, but considers uncertainty about the locations of the curves in Figure 1. This tax is called a "price instrument" because it raises the price of any unit of pollution from $\mathrm{P}^{\circ}$ to $\mathrm{P}^{\prime}$, but then the quantity response is uncertain. Alternatively, government can issue a fixed number of permits that restrict pollution from $Z^{\circ}$ to $Z^{\prime}$, using a "quantity instrument," but then the price response is uncertain.

Using this model, Weitzman shows that the choice between these two types of policies should be based on which type of uncertainty is more costly to bear. If the marginal cost of abatement technologies is steeply sloped, then a fixed limitation on pollution may require firms to undertake very expensive forms of abatement or else pay a very high price for permits. The danger here is that society pays too much for environmental protection. This costly outcome can be avoided by fixing a reasonable price for pollution through a price instrument, and leaving the quantity uncertain. This quantity uncertainty might not be a big problem if it just means that visitors may or may not be able to see clear across the Grand Canyon.

On the other hand, if the marginal cost of pollution is steeply sloped, then an uncertain amount of pollution might generate unreasonably high costs from environmental damages -- rather than loss of visibility, the cost might be loss of lives. If the government sets a price for pollution, in order to avoid high abatement costs, then the danger is that the policy might not abate pollution enough to prevent "catastrophic" costs such as deaths from a temperature inversion. This danger can be avoided by fixing the quantity of pollution below the critical threshold, but then society faces uncertainty about the price of permits or cost of abatement.

Thus the optimal choice depends on the relative slopes of the two curves. If the marginal cost of abatement curve is steeper than the marginal cost of pollution, then the government should set the price and leave the quantity uncertain. But if the marginal cost of pollution is steeper than the marginal cost of abatement, the optimal policy is to

20. Some of the relevant models appear in Hanley, Shogren, and White (1997, 79-84). 
set the quantity. ${ }^{21}$

\section{Political and Ethical Considerations}

In choosing a policy to propose, planners need to consider political feasibility. Even the "social welfare maximizing" policy is pointless if it cannot pass the Congress. In the current political climate, a new "tax" might be DOA -- Dead on Arrival. The Pigouvian subsidy might be equally pointless if it costs revenue that must be covered by raising any existing tax. Instead, various sorts of CAC regulations have been popular, perhaps because costs to consumers are not so explicit. Using a regulatory mandate, legislators can "guarantee" to their constituents that pollution will be controlled, whereas a tax must rely on the theory that firms will be induced to cut pollution. Also, existing firms may provide more support for a plan to allocate tradeable permits -- at no cost to existing firms -- than for a plan to tax all emissions. ${ }^{22}$

A related objective involves ethical or moral considerations. One view is that pollution is a "crime against nature" that ought to be stigmatized by legal regulations rather than condoned by the mere payment of a tax. Religious conviction might be unrelated to apparent self-interest, cost-efficient abatement, or even usual business practices. Such behavior might be difficult to fit into an economic model. Even in existing game-theoretic models of political decision-making, environmentalists might lobby for certain institutional constraints rather than for efficient incentive instruments that minimize abatement costs of firms.

Firms may agree to those arbitrary constraints, especially if those constraints help generate scarcity rents. Row 3 a of Table 1 shows how quantity constraints can help clean the environment and provide profits to firms, allowing those two groups to form a very powerful coalition (Buchanan and Tullock, 1975). One might think that new regulations would raise costs and thus reduce profits and stock prices, but Maloney and McCormick (1982) find that the imposition of new cotton dust standards had the effect of raising stock prices of textile companies. Thus the theory underlying row $3 \mathrm{a}$ of Table 1 has been tested and confirmed.

This surprising alliance of environmentalists and industrialists arises from gains that are concentrated for those two groups in combination with loses to consumers that are very diffuse. The consumers who lose may be politically inactive. Moreover, as shown by Fullerton and Metcalf (2001), the quantity restrictions may be more expensive than other CAC policies that can improve the environment without generating scarcity

21. The optimal policy also is affected if the uncertainty in the marginal cost of pollution is correlated with the uncertainty in the marginal cost of abatement (Stavins, 1996).

22. See Keohane, Revesz, and Stavins (1999) or Joskow and Schmalensee (1998). 
rents. Constraints on the quantity of emissions raise prices to consumers both because of the higher costs of abatement technologies and because those prices provide profits to firms. Thus costs are higher than necessary to protect the environment, and indeed, may exceed the gains from protection of the environment. The problem is how to design an economically-efficient policy proposal that also garners broad support from environmentalists, business, and consumers.

\section{Equity and Distributional Effects}

The first half of this paper outlines distributional effects among consumers who pay higher prices, stockholders who may receive profits, and "victims" of pollution who may gain from environmental protection. Yet these are not really different individuals. Most of us play all three roles. The important questions then involve the net effect on different demographic categories. The goal of fairness can consider distributional effects between urban and rural populations, between young and old, between men and women, or between different income groups. Thus a full analysis would use data on a large sample of households divided into categories, in order to calculate each group's net gain or loss -- including effects on each group from price changes, profits, and benefits of environmental protection.

Little research is available on what income groups gain from environmental protection (Baumol and Oates, 1988). Even less research investigates the distributional effects of profits generated by environmental regulation. Most of the existing distributional measurements pertain to effects from higher prices. ${ }^{23}$ Much of this literature follows the basic methodologies developed in the study of tax incidence generally, as applied to environmental taxes specifically.

Other concepts from the tax incidence literature are also quite useful for the analysis of environmental regulations. First, the concept of "vertical equity" is concerned with the relative treatment of individuals up and down the income spectrum. When environmental regulations raise certain output prices, we want to know whether low-income groups or high-income groups spend a higher than average fraction of their incomes on those products. We also want to know the effect on different income groups of change in profits or benefits of environmental protection.

Second, the concept of "horizontal equity" is concerned with the relative treatment of individuals at the same income level. In other words, one goal of fairness might be to minimize the extent to which a new law treats similar people differently. If a new toxic waste incinerator must be placed in one neighborhood or another with similar characteristics, then compensation might be necessary in order to avoid imposing a very arbitrary pattern of losses on one group or the other. Of two individuals 
at the same income level, one may spend more on the good whose price rises, one may own more stock in the regulated industry, and one may benefit more from environmental protection. Certainly some people live in unpolluted areas while others in cities suffer from respiratory illnesses and would benefit disproportionately from cleaner air.

A third concept of equity, in the case of environmental damages, is the "polluter pays principle." This concept was discussed above as a principle of economic efficiency, where the objective of the tax is to collect a marginal price per unit of pollution, in order to discourage pollution. But it can also be interpreted as a principle of fairness, where the objective of the tax is to collect appropriate total amounts from the parties responsible for pollution. A tax might be used to achieve this latter objective without the former. An example is the U.S. tax on chemical feedstocks, devoted to cleanup of abandoned contaminated sites under the Superfund program. This tax may collect from the firms that were responsible for that pollution, for retroactive equity, but it does not improve efficiency by providing incentives to reduce the prospective generation of waste, unsafe disposal of that waste, or the abandonment of contaminated sites.

This retroactive equity version of the polluter-pays principle has a problem. Even if a smokestack firm was "responsible" for the pollution, that firm may not have received any benefits from avoiding the full social cost of it. With competition and constant returns to scale, for example, the firm was making zero profits in equilibrium. If the firm faced the lower cost of production (PMC in Figure 1), then consumers benefited from the lower price $\left(\mathrm{P}^{\circ}\right)$. Moreover, any attempt to collect from the "responsible firm" is likely to affect current shareholders who may not even have been owners at the time the pollution took place. It is impossible after the fact to collect from the past shareholders or the past consumers who benefitted from the past pollution. For these reasons, the retroactive equity version of the polluter pays principle does not work. In contrast, the prospective efficiency version of the polluter pays principle can both discourage pollution and make consumers pay for the full social cost of the goods they buy.

\section{Other Distortions}

The implementation of a Pigouvian tax or other environmental regulation might be complicated by the concern for other policy goals related to other taxes, market structure, monopoly power, trade agreements, and international competitiveness (Barthold, 1994).

For the simplest example, consider a perfectly competitive market for a good with constant private marginal cost (PMC), fixed pollution per unit of output, and no other distortions. Then Figure 1 can be used to represent the output market, where 
social marginal cost (SMC) exceeds PMC, so the competitive market produces "too much" output. In contrast, the usual problem with a non-competitive market is that a monopoly or oligopoly would produce "too little" output. Now suppose the market suffers from both problems at once: if a monopolist restricts output of a good that also pollutes the environment, then does it produce too much output or too little output? This simple example illustrates the "Theory of the Second Best" (Lipsey and Lancaster, 1956-7). Since one distortion may offset another, a social-welfare-maximizing policymaker cannot just try to reduce the number of distortions in a market. If the antitrust problem remains unresolved, then any attempt to fix the pollution problem with a Pigouvian tax or other output restriction may reduce social welfare.

Similarly, U.S. policymakers have international trade objectives, human rights objectives, and even military objectives. Even if all Americans agreed unanimously on a particular environmental objective, we might still need to forego that goal in order to achieve one or more of the other objectives. In international negotiations, for example, the U.S. may press China to open its borders for trade, stop human rights abuses, allow democratic elections, stop selling arms to Iraq, and reduce carbon dioxide emissions from burning fossil fuel. U.S. negotiators certainly will not achieve all of these objectives, so they must choose which objectives are most important and attainable. In addition, these international objectives may influence policymakers' choices among the domestic environmental policies listed in the first half of this paper. Coordination with our allies and trading partners may or may not require policies similar to theirs. ${ }^{24}$

Another set of issues concerns interactions between environmental policy and tax policy. As pointed out in the debate about the "double-dividend hypothesis," 25 environmental policies can have some of the same distorting effects as tax policies by raising product prices, reducing the real net wage received by workers, and therefore exacerbating labor supply distortions. Thus a shift from a labor tax to an environmental

24. These considerations touch on two of the biggest current debates of environmental policy. These debates cannot possibly be described fully here, but they need to be mentioned so that interested readers can find further references. One debate concerns whether a country with lax environmental standards can become a "pollution haven" with an unfair competitive advantage. An overview of this debate appears in Cooper (1994). Another debate concerns whether a country with stiff environmental standards can reduce production costs and thus improve international competitiveness. See Porter (1991) and Mohr (2001).

25. The words "double dividend" were first used by Pearce (1991), who suggested that environmental taxes might both improve the environment and improve the tax system by replacing other distorting taxes such as those on labor. However, Bovenberg and de Mooij (1994) show that environmental taxes may distort labor supply as well as consumption choices. Other double dividend literature is reviewed by Goulder (1995) and Fullerton and Metcalf (2001). 
tax may or may not provide two dividends, but the whole point of the Theory of the Second Best is that the count of the number of dividends is irrelevant. To determine the net effect on welfare, an economic model needs to incorporate exacerbating or offsetting effects of all relevant distortions such as existing taxes, environmental externalities, missing insurance markets, oligopoly, and other market failures.

\section{Flexibility and Dynamic Adjustments}

A final set of goals involves the flexibility of the economy to adjust production and the flexibility of the government to adjust policy rules as information and measurement improve. In particular, policy rules should be flexible enough to change with news about the damaging effect of the regulated pollutant, changes in the number of people affected, or changes in weather conditions that affect the spread or severity of the damages. Government may need to be able to change the Pigouvian tax rate, change the number of permits issued, or change the technology restrictions. Since a new Act of Congress is relatively difficult, an issue arises about how much authority needs to be vested in the EPA or other regulators themselves.

In terms of dynamic efficiency, market-based incentives like taxes or permits may provide incentives to conduct the research necessary to develop new cost-effective technologies. No such incentive is provided by a CAC regulation that requires an existing technology.

To make a reform worthwhile, the present value of all future efficiency gains must outweigh the short run costs of adjustment. Those costs include the obsolescence of human and physical capital, the unemployment of workers, the transport of both capital and workers to new industries in new locations, retraining, and the cost in terms of equity from imposing temporary windfall gains and losses on particular groups in society. The reform can include provisions to facilitate the transition, to retrain displaced workers, and to compensate those who lose.

The partial equilibrium model in Figure 1 assumes that all other prices are constant, and it assumes perfect mobility, so workers who leave this industry can move costlessly to another industry to find work at the same wage. In other words, area 8 is not a loss. That model ignores the cost of retraining, the cost of moving a family to a different state, and the psychic cost of losing one's job. These costs cannot be ignored. A dramatic but very real example is provided by the following story from the Washington Post. This particular story does not involve government policy, necessarily, but stiff new environmental protections can impose the same kinds of industry cutbacks, disruptions, and job loss:

In January 1991, after a bitter strike, Eastern Airlines grounded its planes forever. In a stroke, the 30,000 highly skilled and well-paid Eastern employees - most of whom had 20 or 30 years with the company -- joined the ranks of the 
jobless. Just 11 months later, Pan Am, the one-time aviation giant, went under. When its remaining 12,000 employees arrived at work on Dec. 4, 1991, security staff gave them one hour to clear out. A year and a half later, suicide among these laid off workers has reached epidemic proportions. Since Pan Am's demise, eight former employees have killed themselves -- double the normal rate for men in their forties and fifties. Since the Eastern strike began in 1989, at least 14 former employees have killed themselves, as did the wife of an Eastern pilot. In one case, a mechanic also shot his children. ${ }^{26}$

\section{Tradeoffs Among the Objectives}

To discuss more of the tradeoffs among these eight categories of goals and objectives, return to the example of the U.S. tax on gasoline. It does provide some incentive to reduce pollution by driving less, and it is large enough to cover the administrative cost of collecting the tax, but the rate is not necessarily high enough to cover all the environmental damages per unit of gasoline consumed. Those damages are extremely high in congested major cities, ${ }^{27}$ but may be very low in unpopulated areas. Thus a single national gasoline tax cannot always reflect the external damages, and therefore loses some economic efficiency, but a geographically-differentiated gasoline tax would be difficult to administer (and perhaps unconstitutional). These may be some of the reasons that the U.S. has adopted CAC rules that can differ among Air Quality Control Regions (AQCR) such as in Southern California.

In general, a reform can be designed to improve economic efficiency by applying a tax (or permit price) directly to some measurable pollutants, in a way that effectively induces polluters to abate, but the increased economic efficiency may come at some cost in terms of administrative efficiency, costs of monitoring, and difficulty of enforcement. As mentioned above, a regulation that all firms must have a scrubber is easier to monitor and enforce than a tax per unit of waste.

If information about the effects of a pollutant is difficult or expensive for the government to obtain, then the scope for policy is limited. Reliance on the Coase (1960) solution can help overcome this problem, since the affected parties have better information and can take their own actions against polluters. The Coase solution is also flexible to changing circumstances, since the affected parties can re-contract. On the other hand, the Coase solution usually involves bargaining costs and litigation. Also, if exclusion is imperfect and other affected parties are not taken into account, then the Coase solution is not perfectly efficient. Nonetheless, for some pollution problems, the

26. Barbara Koeppel, "For Airline Workers the Crash Can Be Fatal," Washington Post, Sunday, September 5, 1993.

27. For the Los Angeles region alone, estimates of annual health damages range from \$3.6 to \$20 billion in 1992 dollars (Hall et al, 1992; Krupnick and Portney, 1991). 
information and flexibility advantages of the Coase solution may more than offset these costs.

In addition, we must expect tradeoffs between economic efficiency and distributional equity. On the one hand, much environmental degradation is concentrated in cities and neighborhoods with relatively low income households (Been, 1994). The benefits of reducing this pollution may accrue disproportionately to low income households. On the other hand, the benefits of many environmental policies accrue disproportionately to high-income households who have met all their basic needs in terms of food and shelter and who then desire "luxuries" such as a pristine wilderness with clean air and greater visibility. ${ }^{28}$ The poor family may prefer improved nutrition, housing, education, or other goods. At the same time, the distribution of the costs of pollution protection may also be regressive. ${ }^{29}$ Thus we face the prospect that at least some environmental programs impose burdens disproportionately on poor groups while providing benefits disproportionately to rich groups. Such an outcome has implications not only for the equity of environmental policy, but for political feasibility as well. Moreover, any attempt to alter the policy to redistribute the burdens and benefits may also make the policy less-well targeted in terms of economic efficiency or other goals listed above.

The goal of flexibility may conflict with another desirable objective of policy, that is, to provide business with a more certain set of tax rates and policy rules. Frequent changes in tax rules or environmental regulations can discourage capital formation by making investors even more uncertain about their future net returns. Since investment is already discouraged by taxes on income from capital, this uncertainty about policy can reduce economic efficiency. In other words, incentives can be perverted by attempts to "change the rules in the middle of the game." Thus the gains from having the new rules must be large enough to offset the losses associated with making any change at all.

The goal of certainty also relates to considerations of equity, because any change in policy can result in windfall gains and losses through capitalization into asset prices. Consider the decision to set aside "critical habitat," or the decision about where to put a toxic waste incinerator. Each such policy decision can reduce certain land prices and impose large windfall losses on particular owners. Some other landowners may experience increased market value. These policy decisions violate horizontal equity, if two similar landowners experience such different outcomes, and they may violate vertical equity as well if low-income neighborhoods are adversely affected. Similarly,

28. See the discussion in Baumol and Oates (1988, Chapter 15) and Freeman (1972).

29. See Gianessi and Peskin (1980) or Robison (1985). 
any new technology requirement may reduce a company's stock price, just as Maloney and McCormick (1982) showed that a new quantity restriction can raise a company's stock price. Until we know more about the ownership of these companies, the pattern of gains and losses must be considered capricious and arbitrary.

Policy interactions have complicated effects on each of these competing goals and objectives, so we have no guarantee that current policy strikes the best balance among them. Moreover, technology and social priorities change continually. Thus a reform may be able to improve upon these tradeoffs. Ideally, a reform may be able to improve upon one or more of these objectives without sacrificing other objectives. As a general matter, however, a reform cannot obtain something for nothing. Greater economic efficiency may come at some other cost, and the perennial problem of policymakers is to design reforms that best balance the competing objectives. The framework suggested in this paper can be used to make the tradeoffs explicit, to choose among alternative proposals, and thus to design better policy. 


\section{Table 1}

\section{Different Distributional Effects of Alternative Policies}

\begin{tabular}{|c|c|c|c|c|c|}
\hline \multirow{2}{*}{$\begin{array}{l}\text { Alternative } \\
\text { Policies }\end{array}$} & \multicolumn{4}{|c|}{ The Effect of the Change on Each Group } & \multirow{2}{*}{$\begin{array}{l}\text { Overall } \\
\text { Net } \\
\text { Effect } \\
\text { (row } \\
\text { sum) }\end{array}$} \\
\hline & Consumers & $\begin{array}{l}\text { Firms' } \\
\text { Profits }\end{array}$ & $\begin{array}{c}\text { Gov't } \\
\text { Revenue }\end{array}$ & Victims & \\
\hline \multicolumn{6}{|l|}{ 1. Pigouvian Solutions } \\
\hline a. tax on pollution & $-(2+3+4)$ & 0 & $2+3$ & $4+5+6$ & $5+6$ \\
\hline b. subsidy to abate & $-(2+3+4)$ & $2+3+4+5$ & $-(4+5)$ & $4+5+6$ & $5+6$ \\
\hline \multicolumn{6}{|l|}{ 2. Permits } \\
\hline a. handed out to firms & $-(2+3+4)$ & $2+3$ & 0 & $4+5+6$ & $5+6$ \\
\hline b. sold at auction & $-(2+3+4)$ & 0 & $2+3$ & $4+5+6$ & $5+6$ \\
\hline \multicolumn{6}{|l|}{ 3. Command and Control } \\
\hline a. quantity restriction & $-(2+3+4)$ & $2+3$ & 0 & $4+5+6$ & $5+6$ \\
\hline b. quantity and price & -4 & 0 & 0 & $4+5+6$ & $5+6$ \\
\hline \multicolumn{6}{|l|}{ 4. Coase Solution } \\
\hline a. "victim" has rights & $-(2+3+4)$ & $2+3-\mathrm{B}$ & 0 & $\begin{array}{c}4+5+ \\
6+B\end{array}$ & $5+6$ \\
\hline b. polluter has rights & $-(2+3+4)$ & $2+3+\mathrm{C}$ & 0 & $\begin{array}{c}4+5+ \\
6-\mathrm{C}\end{array}$ & $5+6$ \\
\hline
\end{tabular}


Figure 1

Equivalent Efficiency Effects of Alternative Policies

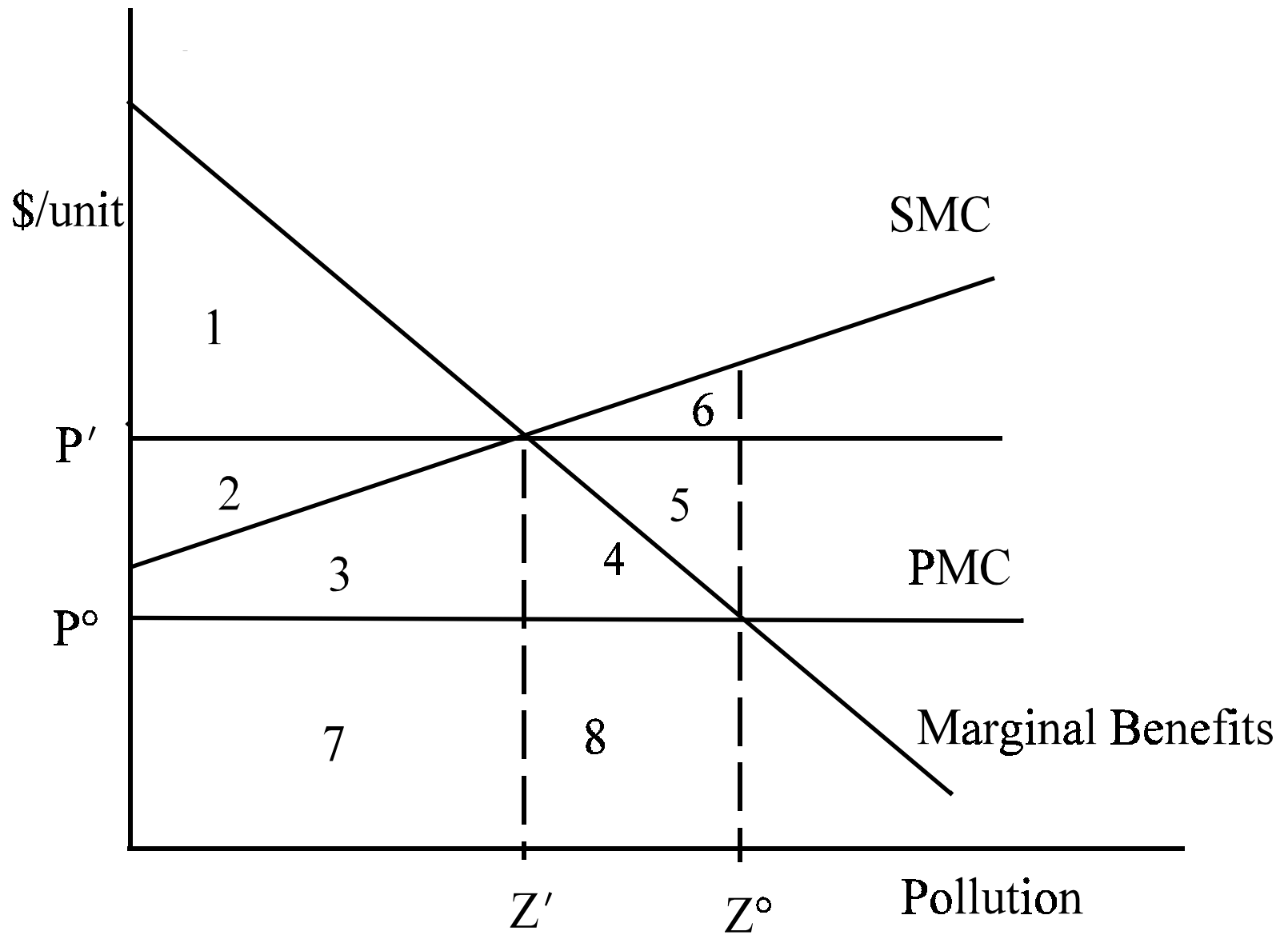


$-\mathrm{R} 1-$

\section{References}

Alberini, Anna, David Edelstein, Winston Harrington, and Virginia D. McConnell. 1994. Reducing Emissions from Old Cars: The Economics of the Delaware Vehicle Retirement Program. Washington DC: Resources for the Future, Discussion Paper 94-27.

Atkinson, Scott E., and Donald H. Lewis. 1974. A Cost-Effectiveness Analysis of Alternative Air Quality Control Strategies. Journal of Environmental Economics and Management 1:237-50.

Ballard, Charles L., and Steven G. Medema. 1993. The Marginal Efficiency Effects of Taxes and Subsidies in the Presence of Externalities: A Computational General Equilibrium Approach. Journal of Public Economics 52:199-216.

Barthold, Thomas A. 1994. Issues in the Design of Environmental Excise Taxes. Journal of Economic Perspectives 8:133-51.

Baumol, William J., and Wallace E. Oates. 1988. The Theory of Environmental Policy. New York: Cambridge University Press.

Been, Vicki. 1994. Locally Undesirable Land Uses in Minority Neighborhoods:

Disproportionate Siting or Market Dynamics?. Yale Law Journal 103:1383-422.

Bohm, Peter, and Clifford F. Russell. 1985. Comparative Analysis of Alternative Policy Instruments. In Handbook of Natural Resource and Energy Economics, Vol. 1, edited by A. V. Kneese and J. L. Sweeney. New York: Elsevier, pp. 395-460.

Bovenberg, A. Lans, and Ruud A. de Mooij. 1994. Environmental Levies and Distortionary Taxation. American Economic Review 94:1085-89.

Break, George F., and Joseph A. Pechman. 1975. Federal Tax Reform: The Impossible Dream?. Washington DC: The Brookings Institution.

Buchanan, James M., and Gordon Tullock. 1975. Polluters' Profits and Political Response: Direct Controls Versus Taxes. American Economic Review 65:13947.

Burmich, Pam. 1989. The Air Pollution - Transportation Linkage. Sacramento, CA: State of California Air Resources Board, Office of Strategic Planning.

Coase, Ronald. 1960. The Problem of Social Cost. Journal of Law and Economics 3:144.

Cooper, Richard N. 1994. Environmental and Resource Policies for the World Economy. Washington DC: The Brookings Institution.

Cropper, Maureen L., and Wallace E. Oates. 1992. Environmental Economics: A Survey. Journal of Economic Literature 30:75-740.

Freeman, A. Myrick. 1972. The Distribution of Environmental Quality. In Environmental Quality Analysis: Theory and Method in the Social Sciences, 
edited by A. Kneese and B. Bower. Baltimore: The Johns Hopkins Press.

Fullerton, Don, and Gilbert E. Metcalf. 2001. Environmental Controls, Scarcity

Rents, and Pre-Existing Distortions. Journal of Public Economics 80:249-67.

Gianessi, Leonard P., and Henry M. Peskin. 1980. The Distribution of the Costs of Federal Water Pollution Control Policy. Land Economics 56:85-102.

Gordon, Roger. 1989. Do Publicly Traded Corporations Act in the Public Interest?. Ann Arbor, MI: University of Michigan.

Goulder, Lawrence H. 1995. Environmental Taxation and the 'Double Dividend': A Reader's Guide. International Tax and Public Finance 2:157-83.

Goulder, Lawrence H., Ian W. H. Parry, and Dallas Burtraw. 1997. Revenue-Raising vs. Other Approaches to Environmental Protection: The Critical Significance of Pre-Existing Tax Distortions. RAND Journal of Economics 28: 708-31.

Hahn, Robert. 1989. Economic Prescriptions for Environmental Problems: How the Patient Followed the Doctor's Orders. Journal of Economic Perspectives 3:95114.

Hall, J., A. Winer, M. Kleinman, F. Lurmann, V. Brajer, and S. Colome. 1992. Valuing the Health Benefits of Clean Air. Science 225:812-7.

Hanley, Nick, Jason F. Shogren, and Ben White. 1997. Environmental Economics: In Theory and Practice. New York: Oxford University Press.

Harrington, Winston, Margaret A. Walls, and Virginia McConnell. 1994. Shifting Gears: New Directions for Cars and Clean Air. Washington, DC: Resources for the Future, Discussion Paper 94-26-REV.

Joskow, Paul L., and Richard Schmalensee. 1998. The Political Economy of Marketbased Environmental Policy: The U.S. Acid Rain Progam. Journal of Law and Economics 41:37-84.

Kaplow, Louis, and Steven Shavell. 1997. On the Superiority of Corrective Taxes to Quantity Regulation. Cambridge, MA: National Bureau of Economic Research, Working Paper \#6251.

Keohane, Nathaniel O., Richard L. Revesz, and Robert N. Stavins. 1999. The Positive Political Economy of Instrument Choice in Environmental Policy. In Environmental Economics and Public Policy: Essays in Honor of Wallace E. Oates, edited by P. Portney and R. Schwab. London: Edward Elgar.

Krueger, Anne O. 1974. The Political Economy of the Rent-Seeking Society. American Economic Review 64:291-303.

Krupnick, Alan J., and Paul R. Portney. 1991. Controlling Urban Air Pollution: A Benefit-Cost Assessment. Science 252:522-28.

Lipsey, R. G., and K. Lancaster. 1956-7. The General Theory of Second Best. Review of Economic Studies 24:11-32. 
Maloney, Michael T., and Robert E. McCormick. 1982. A Positive Theory of Environmental Quality Regulation. Journal of Law and Economics 25:99-123.

Metcalf, Gilbert E. 1999. A Distributional Analysis of Green Tax Reforms. National Tax Journal 52:655-81.

Mohr, Robert. 2001. Technical Change, External Economies and the Porter Hypothesis. Journal of Environmental Economics and Management, forthcoming.

Parry, Ian W. H. 1997. Environmental Taxes and Quotas in the Presence of Distorting Taxes in Factor Markets. Resource and Energy Economics 19:203-20.

Parry, Ian W. H. 1998. A Second-Best Analysis of Environmental Subsidies. International Tax and Public Finance 5:157-74.

Pearce, David. 1991. The Role of Carbon Taxes in Adjusting to Global Warming. The Economic Journal 101:938-48.

Pigou, Arthur C. 1932. The Economics of Welfare. Fourth Edition. London: MacMillan and Co.

Porter, Michael E. 1991. America's Green Strategy. Scientific American 264:168.

Robison, H. David. 1985. Who Pays for Industrial Pollution Abatement?. Review of Economics and Statistics 67:702-6.

Rogers, Diane. 1995. Distributional Effects of Corrective Taxation: Assessing Lifetime Incidence from Cross-Sectional Data. Proceedings of the National Tax Association (meetings of 1994), 192-202.

Russell, Clifford. 1990. Monitoring and Enforcement. In Public Policies for Environmental Protection, edited by P. R. Portney. Washington, DC: Resources for the Future, distributed by Johns Hopkins University Press, Baltimore, pp.243-74.

Seskin, Eugene P., Robert J. Anderson, and Robert O. Reid. 1983. An Empirical Analysis of Economic Strategies for Controlling Air Pollution. Journal of Environmental Economics and Management 10:112-24.

Sierra Research. 1994. Analysis of the Effectiveness and Cost-Effectiveness of Remote Sensing Devices. Sacramento, CA: Report No. SR94-05-05, prepared for the U.S. Environmental Protection Agency by Sierra Research. Slemrod, Joel. 1990. Optimal Taxation and Optimal Tax Systems. Journal of Economic Perspectives 4:157-78.

Slemrod, Joel, and Marsha Blumenthal. 1993. The Income Tax Compliance Cost of Big Business. Washington DC: Tax Foundation.

Slemrod, Joel, and Nikki Sorum. 1984. The Compliance Cost of the U.S. Individual Income Tax System. National Tax Journal 37:461-74.

Stavins, Robert N. 1995. Transaction Costs and Tradeable Permits. Journal of Environmental Economics and Management 29:133-48.

Stavins, Robert N. 1996. Correlated Uncertainty and Policy Instrument Choice. Journal 
of Environmental Economics and Management 30:218-32.

Stavins, Robert N. 2000. Market-Based Environmental Policies. In Public Policies for Environmental Protection, edited by P. Portney and R. Stavins. Washington DC: Resources for the Future.

Walls, Margaret and Jean Hanson. 1999. Distributional Aspects of an Environmental Tax Shift: The Case of Motor Vehicle Emissions Taxes. National Tax Journal 52:53-65.

Weitzman, Martin L. 1974. Prices vs. Quantities. Review of Economic Studies 41:477-91. 